\title{
GENERATION OF METAL NANOPARTICLES BY LASER ABLATION
}

\author{
V. Dudoitis, V. Ulevičius, G. Račiukaitis, N. Špirkauskaitè, and K. Plauškaitė \\ State Research Institute Center for Physical Sciences and Technology, Savanoriu 231, LT-02300 Vilnius, Lithuania \\ E-mail: ulevicv@ktl.mii.lt
}

Received 2 June 2011; revised 11 July 2011; accepted 21 September 2011

\begin{abstract}
The process of nanoparticle generation during nanosecond and picosecond laser ablation of various metals $(\mathrm{Ni}, \mathrm{Al}, \mathrm{W}$, and stainless steel) in ambient air and argon gas was investigated. The number concentration of nanoparticles generated by laser ablation in argon gas was up to 100 times higher compared to that in ambient air. Three stable separate size peaks of nucleation, Aitken, and accumulation modes of nanoparticles were observed in case of argon gas, while in ambient air particles of a wide size spectrum $(8-200 \mathrm{~nm})$ were generated. The natural precursors in ambient air can have an effect on the size spectrum of particles composed of various chemical compounds with target material during the ablation process. The influence of laser process parameters and properties of investigated metals on the number concentration and size distribution of nanoparticles generated during ns- and ps-laser ablation was observed.
\end{abstract}

Keywords: nanoparticles, nanosecond and picosecond laser ablation, metals, size distribution, number concentration, ambient air, argon gas

PACS: 52.38.Mf, 78.70.-g, 81.10.St

\section{Introduction}

Comprehension of the aerosol formation as inevitable process in laser micromachining technology is established and the application of laser ablation in production of nanoparticles is widely spread. However, characteristics of particles generated by laser ablation are not fully known. Therefore, the studies of particle concentration and their size distribution are hot topics in current laser ablation investigations recently [1-9]. Nanoparticle generation by laser ablation is used for a variety of applications such as biotechnology, electronic industry, etc. The laser ablation is also an intensive source of submicron particle generation and their possible leakage into ambient air, therefore investigations of the particle formation kinetics in ambient air during laser processing are essential for the evaluation of potential generation of particle emission and their impact on human health [7]. For example, during laser processing particles formed of metals (e.g. iron, aluminium), especially toxic (e.g. manganese, zinc) or carcinogenic substances (e.g. chromium (VI) compounds, nickel), might penetrate into a human organism and cause health concerns [8, 9].

The physical process of particle generation begins with the absorption of laser irradiation in the beam / material interaction zone. Depending on the wavelength of the laser beam and the material properties, kinetic energy is transformed into thermal (in metals $10^{-13} \mathrm{~s}$ ) [10], which cuts off chemical bonds in material. The phase transition occurs if the energy threshold for that material is reached. As a result, material can be melted, vaporized, or sublimated and the particle generation process begins.

Both the particle concentration and size distribution depend on laser operating parameters such as wavelength, pulse duration, energy, and repetition rate, beam scanning speed $[3,7,10,11]$. Studies show that experimental conditions during laser ablation could be established in order to control the particle size and distribution [1, 3]. Besides, medium (ambient air, argon, water, etc.) in the ablation chamber also plays an important part in the particle formation process. It was experimentally estimated that the mass of generated nanoparticles in ambient air was up to 100 times higher than in water [3].

The aim of the study was to investigate the peculiarities of nanoparticle formation during laser ablation of different metals (nickel, aluminium, stainless steel, tungsten) and to characterize the difference of size distribution of the generated particles in respect of the laser irradiation type (nanosecond, picosecond) and medium in the ablation chamber (partially particle-free ambient air, argon gas). 


\section{Theoretical background}

During the interaction of the laser beam and material, the light absorption is a general physical process $[11-13]$. The energy coupled into material causes thermal heating, melting, and vaporization of material, plasma formation, and particle emission. In metals, free electrons interact with the intense electromagnetic irradiation. The energy is instantly absorbed by electrons and further distributed to the lattice. The laser pulse duration $\tau_{\mathrm{L}}$ is important for understanding what happens with the energy in the laser beam/material interaction zone. $\tau_{i}=\frac{C_{i}}{\gamma}$ is the lattice heating time, $\tau_{e}=C_{e} / \gamma$ is the electron cooling time, where $C_{e}$ and $C_{i}$ are electron and lattice thermal capacities, respectively, and $\gamma$ is the electron-lattice coupling parameter specific to every material. Based on the two-temperature diffusion model by Chichkov et al. [13] the laser beam/material interaction can be described by electron and lattice subsystem temperatures $T_{e}$ and $T_{i}$, respectively:

$$
\begin{aligned}
C_{e} \frac{\partial T_{e}}{\partial t} & =-\frac{\partial Q(z)}{\partial z}-\gamma\left(T_{e}-T_{i}\right)+S, \\
C_{i} \frac{\partial T_{i}}{\partial t} & =\gamma\left(T_{e}-T_{i}\right),
\end{aligned}
$$

where $Q(z)$ is the heat flux, $S$ is the heat source (laser pulse).

For picosecond pulses, condition $\tau_{e} \ll \tau_{\mathrm{L}} \ll \tau_{i}$ holds. The laser pulse duration is shorter than the lattice heating time. Particles from the material are removed partly by solid state-vapour transition and direct breaking of chemical bonds. For picosecond pulses (Eq. (1)) the electron temperature $T_{e}$ becomes quasi-stationary:

$$
\frac{\partial}{\partial z}\left(k_{e} \frac{\partial T_{e}}{\partial z}\right)-\gamma\left(T_{e}-T_{i}\right)+I_{a} \alpha \exp (-\alpha z),
$$

where $k_{e}$ is the electron thermal conductivity, $\alpha$ is the absorption coefficient, $I_{a}$ is the laser intensity transmitted to the material, $z$ is the depth of laser beam penetration into material perpendicular to the surface. In this case, lattice temperature $T_{i}$ is

$$
T_{i}=\frac{t}{\tau_{i}} \int_{0}^{t} \exp \left(-\frac{t-\theta}{\tau_{i}}\right) T_{e}(\theta) \mathrm{d} \theta+T_{0},
$$

where $T_{0}$ is the initial electron temperature.

Taking this into account Eq. (4) can be simplified due to quasi-stationary condition of electron temperature:

$$
T_{i} \approx T_{e}\left[1-\exp \left(-\frac{t}{\tau_{i}}\right)\right] \approx \frac{t}{\tau_{i}} T_{e},
$$

where $t$ is the time after the laser exposure. It means that electron cooling temperature $T_{e}$ remains longer than lattice heating temperature $T_{i}$ after exposure of picosecond laser pulses. Electron cooling temperature $T_{e}$ at the end of the pulse is

$$
T_{e} \approx \frac{I_{a} \alpha}{\gamma} \exp (-\alpha z)
$$

Lattice heating temperature $T_{i}$ at the end of the laser pulse is

$$
T_{i} \approx \frac{F_{a} \alpha}{C_{i}} \exp (-\alpha z),
$$

where $F_{a}$ is the absorbed laser fluence, which is $F_{a}=$ $I_{a} \tau_{\mathrm{L}}$. By using the condition of strong evaporation it can be described as

$$
F_{a} \geq F_{\text {th }} \exp (\alpha z),
$$

where $F_{\text {th }}$ is the threshold laser fluence for evaporation.

Equations (6)-(8) describe how laser intensity, material transmissivity, and thermal capacities influence the temperature of the electron and the lattice.

In the second case for nanosecond pulses, condition $\tau_{\mathrm{L}} \gg \tau_{i} \gg \tau_{e}$ holds. Equations (1),(2) for nanosecond pulses are:

$$
C_{i} \frac{\partial T}{\partial t}=\frac{\partial}{\partial z}\left(k_{0} \frac{\partial T}{\partial z}\right)+I_{a} \alpha \exp (-\alpha z),
$$

where $k_{0}$ is the conventional equilibrium thermal conductivity of the metal and $T$ represents general temperature of the subsystem because in case of ns-laser ablation $T_{e}=T_{i}=T$.

The energy absorbed by electrons is fully transferred to the lattice during the laser pulse duration. Material is heated due to the absorbed energy of the lattice. In this case, solid material melts, the beam/material interaction zone spreads and particles are evaporated from liquid state. Metals have good thermal conductivity properties, thus increasing the energy loss due to the lattice heating for nanosecond pulses.

\section{Experimental set-up}

The experimental set-up is schematically shown in Fig. 1. The main parts are: the laser, the galvoscanner for the laser beam control and an ablation chamber, a differential mobility particle sizer (DMPS) (ELAS$05 M C$, working range: $10-200 \mathrm{~nm})$, and the condensation particle counter (CPC) (UF-02, cut-size at $4.5 \mathrm{~nm})$. Both devices are developed at the Institute of Physics (Lithuania) [14, 15]. 


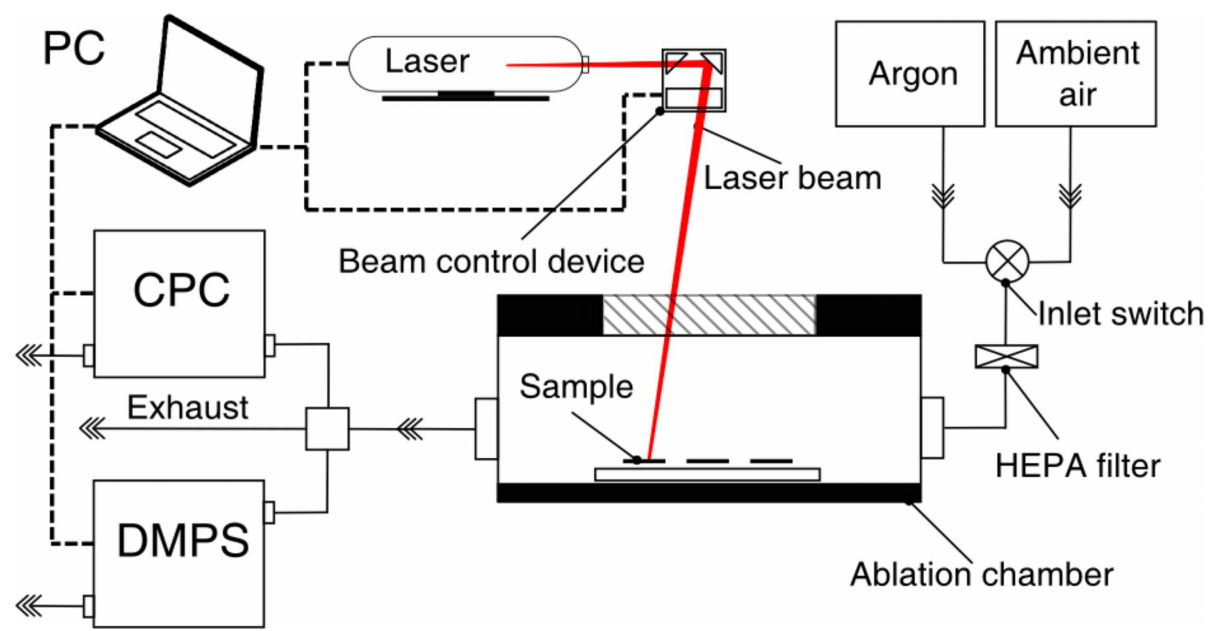

Fig. 1. Experimental set-up for generated particle measurement.

Laser ablation was carried out using two different Nd:YAG lasers: nanosecond (ns) (Ekspla Ltd. NL640, $\lambda=1064 \mathrm{~nm}, 15 \mathrm{~ns}$ ) and picosecond (ps) (Ekspla Ltd. PL10100, $\lambda=532 \mathrm{~nm}, 10 \mathrm{ps).}$

Materials chosen for the investigation were the following metals: stainless steel, nickel, aluminium, and tungsten. The experiments were performed in the ablation chamber at atmospheric pressure with a constant flow of partially particle-free ambient air which was processed through a HEPA filter. It cleaned gas flow from particles up to $5 \mathrm{~nm}$. In the case of argon, the gas was delivered into the chamber from a pressurized tank at a constant flow rate of $3000 \mathrm{~cm}^{3} / \mathrm{min}$. The exhaust flow was divided for the CPC and DMPS measurements. In the case of argon, only DMPS was used. The flow rate for DMPS was $21 / \mathrm{min}$ and $0.31 / \mathrm{min}$ [15] for CPC. The ambient air temperature at the inlet was $25 \pm 2^{\circ} \mathrm{C}$, the argon temperature was $18 \pm 1^{\circ} \mathrm{C}$, relative humidity $25-30 \%$.

The movement of the laser beam was controlled by a galvoscanner. During the experiments, a laser beam was moving in the form of zigzag, filling a square $\left(5 \times 5 \mathrm{~mm}^{2}\right)$. It means that the faster moved the beam, the less time it took to fill a square and to start over ablating the same area again. The laser beam focus diameter $D$ and area $S$ in the case of the ns-laser were $D=40 \pm 5 \mu \mathrm{m}, S=1.26 \cdot 10^{-5} \mathrm{~cm}^{2}$; in the case of the ps-laser $D=20 \pm 5 \mu \mathrm{m}, S=3.14 \cdot 10^{-6} \mathrm{~cm}^{2}$.

The nanosecond laser process parameters were: the average power $0.1-3 \mathrm{~W}$, the pulse repetition rate $1-$ $40 \mathrm{kHz}$, and the beam scanning speed 10-1000 mm/s. Those of the picosecond laser: the average power $0.1-$ $2 \mathrm{~W}$, the pulse repetition rate $50 \mathrm{kHz}$ or $100 \mathrm{kHz}$, and the beam scanning speed $10-1000 \mathrm{~mm} / \mathrm{s}$. For data analysis of the size distribution of generated particles

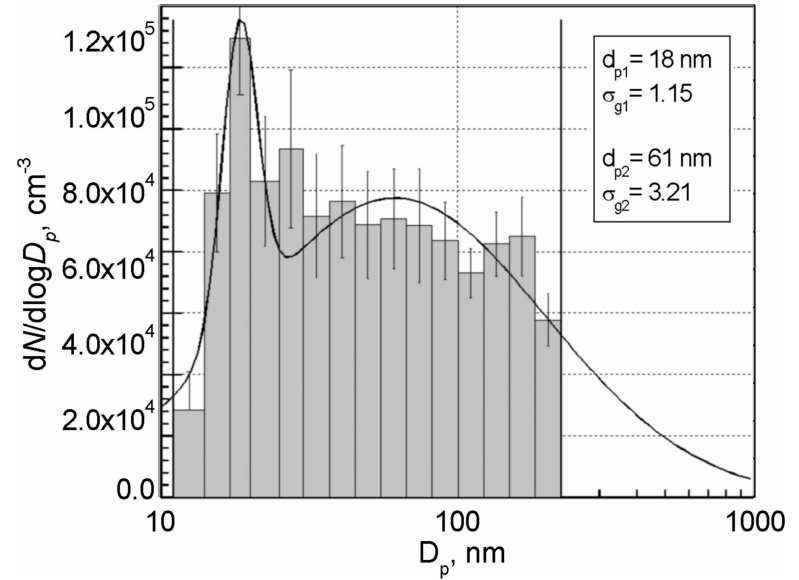

Fig. 2. Particle size $D_{\mathrm{p}}$ distribution for the ns-laser ablation of nickel in ambient air at $0.4 \mathrm{~W}, 10 \mathrm{kHz}, 200 \mathrm{~mm} / \mathrm{s}$, and $12.73 \mathrm{~J} / \mathrm{cm}^{2}$.

by laser ablation in ambient air the Aitken classification of atmospheric aerosol particle modes was used [16].

\section{Results}

Samples were placed into the chamber and it was filled with the operating gas. The laser beam was scanned over the sample surface and both techniques were applied to measure the particles in the exhaust gasses. During the experiments the particle size distribution was averaged from 3 to 8 measurements. The geometric mean of the particle size diameter $d_{\mathrm{p}}$ and the standard deviation $\sigma_{g}$ were calculated. Solid curves in Figs. 2, 3, 5 were obtained by fitting the data using DistFit program [17].

Nickel. Particle generation data by ps- and ns-laser ablation of nickel in ambient air are shown in Figs. 2 and 3. As seen, the processes involved in particle formation were partially different. Smallest particles of $8 \mathrm{~nm}$ size (nucleation mode) with the concentration up 

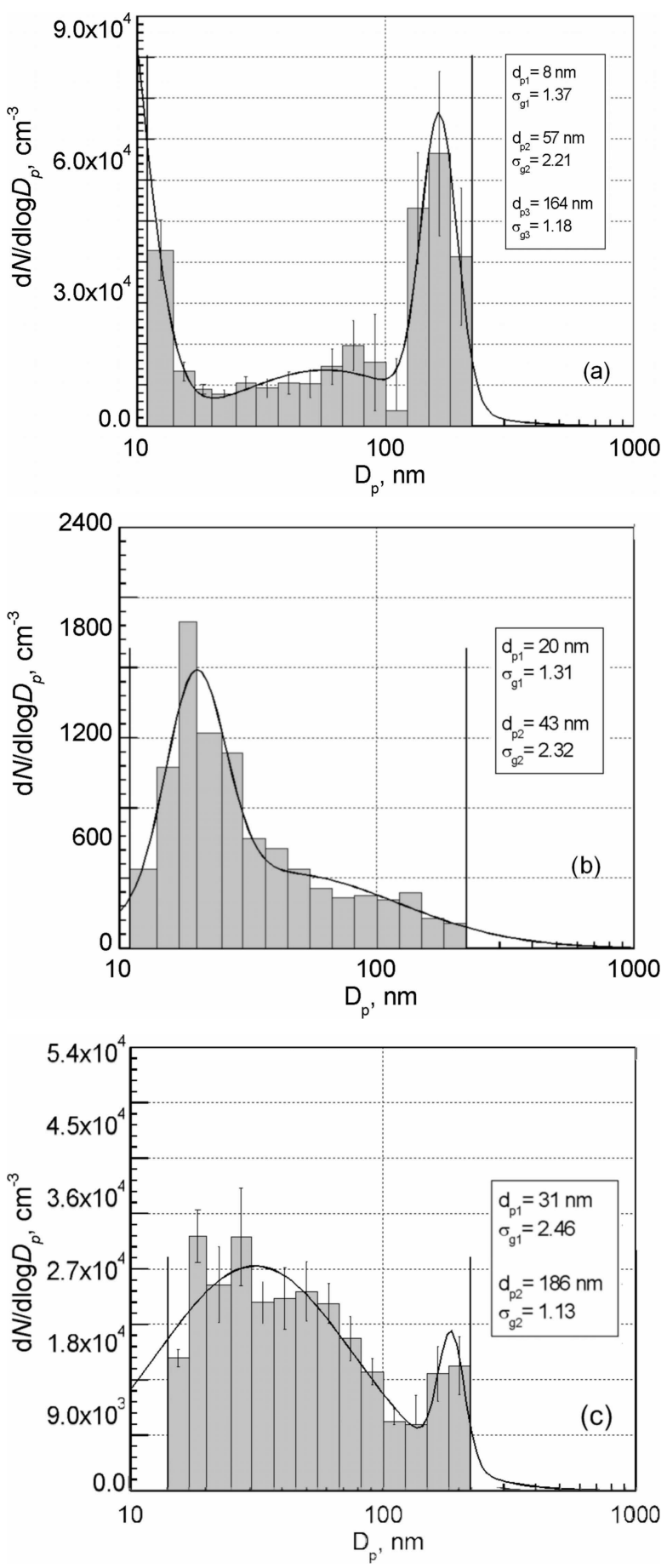

Fig. 3. Particle size $D_{\mathrm{p}}$ distribution for the ps-laser ablation in ambient air: (a) nickel at $0.25 \mathrm{~W}, 100 \mathrm{kHz}, 10 \mathrm{~mm} / \mathrm{s}$, and $0.80 \mathrm{~J} / \mathrm{cm}^{2}$; (b) aluminium at $0.6 \mathrm{~W}, 50 \mathrm{kHz}, 10 \mathrm{~mm} / \mathrm{s}$, and $3.82 \mathrm{~J} / \mathrm{cm}^{2}$; (c) tungsten at $0.25 \mathrm{~W}, 100 \mathrm{kHz}, 1000 \mathrm{~mm} / \mathrm{s}$, and $0.80 \mathrm{~J} / \mathrm{cm}^{2}$.

to $5 \cdot 10^{4} \mathrm{~cm}^{-3}$ were observed in the case of the ps-laser. Particles generated in the nucleation mode with the size of $18 \mathrm{~nm}$ and with three times higher number concentration were observed during ns-laser ablation as well (see Table 1). However, in the case of the ns-laser ablation, a wide size spectrum of particles from 10 to $180 \mathrm{~nm}$ with a sharp peak only in the nucleation mode was observed (Fig. 2). CPC data showed a growth of the particle number concentration in time during the laser ablation (Fig. 4(a)).

Sharp peaks of the nucleation, Aitken, and accumulation modes at 8, 57, and $164 \mathrm{~nm}$, respectively, were observed in the particle size distribution during the ps-laser ablation (Fig. 3(a)). Particle number concentrations of these modes were $(5.0 \pm 0.2) \cdot 10^{4}$, $(1.6 \pm 0.15) \cdot 10^{4}$, and $(6.2 \pm 0.15) \cdot 10^{4} \mathrm{~cm}^{3}$, respectively. The CPC data show an intensive particle generation process in the first minutes and a slow declining tendency in time using a different laser beam scanning speed (Fig. 4(b)). The highest nickel particle concentration (up to $1.2 \cdot 10^{5} \mathrm{~cm}^{3}$ ) was generated in ambient air using the ns-laser (Table 1).

Generation of particles was also performed in the argon gas flow. It was observed that generated nickel particles using both types of lasers had a narrow size distribution peaked at $20 \mathrm{~nm}$ with the high number concentration $\left(1.4 \cdot 10^{6} \mathrm{~cm}^{3}\right)$ and the concentration lower by order of magnitude at $107 \mathrm{~nm}\left(2.0 \cdot 10^{5} \mathrm{~cm}^{3}\right)$ using the nslaser and at $8 \mathrm{~nm}\left(1.8 \cdot 10^{5} \mathrm{~cm}^{3}\right)$, at $46 \mathrm{~nm}\left(5.9 \cdot 10^{5} \mathrm{~cm}^{3}\right)$ and at $166 \mathrm{~nm}\left(2.9 \cdot 10^{5} \mathrm{~cm}^{3}\right)$ using the ps-laser ablation (Table 1). Generation of nickel particles by ps-laser ablation, as can be seen in Fig. 5(a,d), was weaker compared to the ns-laser ablation and caused a shift of the size distribution peak from 20 to $46 \mathrm{~nm}$ and to a coarse particle range $(166 \mathrm{~nm})$.

Aluminium. Generation of aluminium particles by the ps-laser ablation in ambient air was inefficient. As seen in Fig. 3(b), generated particles were of nucleation and Aitken modes. The highest number concentration of generated particles was in the nucleation mode at $20 \mathrm{~nm}\left(1.6 \cdot 10^{3} \mathrm{~cm}^{3}\right)$ (Table 1). CPC data showed a rapid sink trend of the particle number concentrations in time (Fig. 4(e)).

The opposite situation was observed in the case of the aluminium particle generation in argon gas using the nslaser compared to the ps-laser. The largest number concentration of particles was measured during the ns-laser ablation. The size spectrum of generated aluminium particles using the ns-laser was similar to that of nickel particles, i.e. two peaks were observed at $21 \mathrm{~nm}$ and 99 nm (Fig. 5(b)). The maximum particle number concentration reached $1.13 \cdot 10^{6} \mathrm{~cm}^{3}$ for the smallest size of $21 \mathrm{~nm}$ (Table 1).

The measurement data showed that the maximum number concentration of generated aluminium particles by the ps-laser was $(1.7-2.5) \cdot 10^{5} \mathrm{~cm}^{-3}$ and it was higher than in the case of the ns-laser, i. e. the particle 
Table 1. Maximum number concentration of generated particles during nanosecond (ns) and picosecond (ps) laser ablation in different media, particle $/ \mathrm{cm}^{3}$.

\begin{tabular}{|c|c|c|c|c|}
\hline \multirow[b]{2}{*}{ Metals } & \multirow{2}{*}{$\begin{array}{l}\text { Laser } \\
\text { type }\end{array}$} & \multicolumn{3}{|c|}{ Aerosol particle modes in the atmosphere } \\
\hline & & $\begin{array}{l}\text { Nucleation } \\
(1-30 \mathrm{~nm})\end{array}$ & $\begin{array}{c}\text { Aitken } \\
(30-130 \mathrm{~nm})\end{array}$ & $\begin{array}{l}\text { Accumulation } \\
(130-200 \mathrm{~nm})\end{array}$ \\
\hline \multicolumn{5}{|c|}{ In ambient air } \\
\hline Nickel (Ni) & ns & $\begin{array}{c}(1.2 \pm 0.2) \cdot 10^{5} \\
(\text { peak at } 18 \mathrm{~nm})\end{array}$ & $\begin{array}{c}(0.90 \pm 0.17) \cdot 10^{5} \\
(\text { peak at } 61 \mathrm{~nm})\end{array}$ & \\
\hline Nickel (Ni) & ps & $\begin{array}{l}(5.0 \pm 0.2) \cdot 10^{4} \\
(\text { peak at } 8 \mathrm{~nm})\end{array}$ & $\begin{array}{c}(1.60 \pm 0.15) \cdot 10^{4} \\
(\text { peak at } 57 \mathrm{~nm})\end{array}$ & $\begin{array}{l}(6.20 \pm 0.15) \cdot 10^{4} \\
(\text { peak at } 164 \mathrm{~nm})\end{array}$ \\
\hline Aluminium $(\mathrm{Al})$ & ps & $\begin{array}{l}(1.6 \pm 0.5) \cdot 10^{3} \\
(\text { peak at } 20 \mathrm{~nm})\end{array}$ & $\begin{array}{l}(0.7 \pm 0.3) \cdot 10^{3} \\
(\text { peak at } 43 \mathrm{~nm})\end{array}$ & \\
\hline Tungsten $(\mathrm{W})$ & ps & $\begin{array}{l}(1.8 \pm 0.2) \cdot 10^{4} \\
(\text { peak at } 31 \mathrm{~nm})\end{array}$ & & $\begin{array}{c}(1.1 \pm 0.2) \cdot 10^{4} \\
(\text { peak at } 186 \mathrm{~nm})\end{array}$ \\
\hline \multicolumn{5}{|c|}{ In argon gas } \\
\hline Nickel (Ni) & ns & $\begin{array}{r}(1.40 \pm 0.03) \cdot 10^{6} \\
(\text { peak at } 20 \mathrm{~nm})\end{array}$ & $\begin{array}{c}(2.0 \pm 0.6) \cdot 10^{5} \\
(\text { peak at } 107 \mathrm{~nm})\end{array}$ & \\
\hline Aluminium $(\mathrm{Al})$ & ns & $\begin{array}{r}(1.13 \pm 0.03) \cdot 10^{6} \\
(\text { peak at } 21 \mathrm{~nm})\end{array}$ & $\begin{array}{l}(3.4 \pm 0.3) \cdot 10^{5} \\
(\text { peak at } 99 \mathrm{~nm})\end{array}$ & \\
\hline $\begin{array}{l}\text { Stainless } \\
\text { steel (302) }\end{array}$ & ns & $\begin{array}{r}(1.86 \pm 0.06) \cdot 10^{6} \\
(\text { peak at } 17 \mathrm{~nm})\end{array}$ & & $\begin{array}{l}(5.8 \pm 0.15) \cdot 10^{5} \\
(\text { peak at } 182 \mathrm{~nm})\end{array}$ \\
\hline Nickel (Ni) & ps & $\begin{array}{l}(1.8 \pm 0.3) \cdot 10^{5} \\
(\text { peak at } 8 \mathrm{~nm})\end{array}$ & $\begin{array}{l}(5.9 \pm 0.3) \cdot 10^{5} \\
(\text { peak at } 46 \mathrm{~nm})\end{array}$ & $\begin{array}{c}(2.9 \pm 0.2) \cdot 10^{5} \\
(\text { peak at } 166 \mathrm{~nm})\end{array}$ \\
\hline Aluminium $(\mathrm{Al})$ & ps & & $\begin{array}{l}(1.7 \pm 0.3) \cdot 10^{5} \\
(\text { peak at } 79 \mathrm{~nm})\end{array}$ & $\begin{array}{c}(2.5 \pm 0.7) \cdot 10^{5} \\
(\text { peak at } 170 \mathrm{~nm})\end{array}$ \\
\hline Tungsten (W) & ps & & $\begin{array}{l}(3.9 \pm 0.4) \cdot 10^{5} \\
(\text { peak at } 36 \mathrm{~nm})\end{array}$ & $\begin{array}{c}(2.5 \pm 0.9) \cdot 10^{5} \\
(\text { peak at } 131 \mathrm{~nm})\end{array}$ \\
\hline
\end{tabular}

size ranged widely from 50 to $200 \mathrm{~nm}$ with two maximums: at 79 and $170 \mathrm{~nm}$ (Fig. 5(e), Table 1).

Tungsten. Generation of tungsten particles by laser ablation was investigated using only the ps-laser in ambient air and argon gas medium. The size distribution of generated particles was completely different in both cases and evidently showed that the particle size distribution strongly depended on the experimental conditions. The highest number concentration $\left(3.9 \cdot 10^{5} \mathrm{~cm}^{-3}\right)$ was found during the ps-laser ablation in argon gas and the particle size distribution in this case was observed in a wide range from 18 to $200 \mathrm{~nm}$ (Table 1). In both media, particles of a narrow size mode were not formed, but a wide size spectrum was observed with a shift to the smaller particle size in ambient air, while in argon gas it was shifted to the coarse particle size (Figs. 3(c) and 5(f)). Measurement in argon gas showed two number concentration peaks at 36 and $131 \mathrm{~nm}$. CPC data of tungsten particle formation are shown in Fig. 4(c, d) during the ns- and the ps-laser ablation. As seen, the dynamics of the generated particle number concentration shows that during ablation in am- bient air and argon gas the production of particles was different.

In the case of tungsten CPC data showed a slight growth of the particle number concentration for the nslaser ablation whereas a small declining tendency in the first six minutes for the ps-laser ablation and a further slow growth of the particle number concentration were observed (Fig. 4(d)).

Stainless steel. The experimental data on generation of particles in stainless steel by the nanosecond laser ablation in argon gas are shown in Fig. 5(c). It should be noted that the particle number concentration reached $1.86 \cdot 10^{6} \mathrm{~cm}^{-3}$ (the distinct peak at $17 \mathrm{~nm}$ ), but the size spectrum of generated particles was ranging to $200 \mathrm{~nm}$. The second small peak at $190 \mathrm{~nm}$ in the size distribution of generated particles was observed.

\section{Discussion}

In this research, as in many cases of such type of investigations $[3,5,10,11,18-20]$, it has been shown that concentration of generated particles and their size 

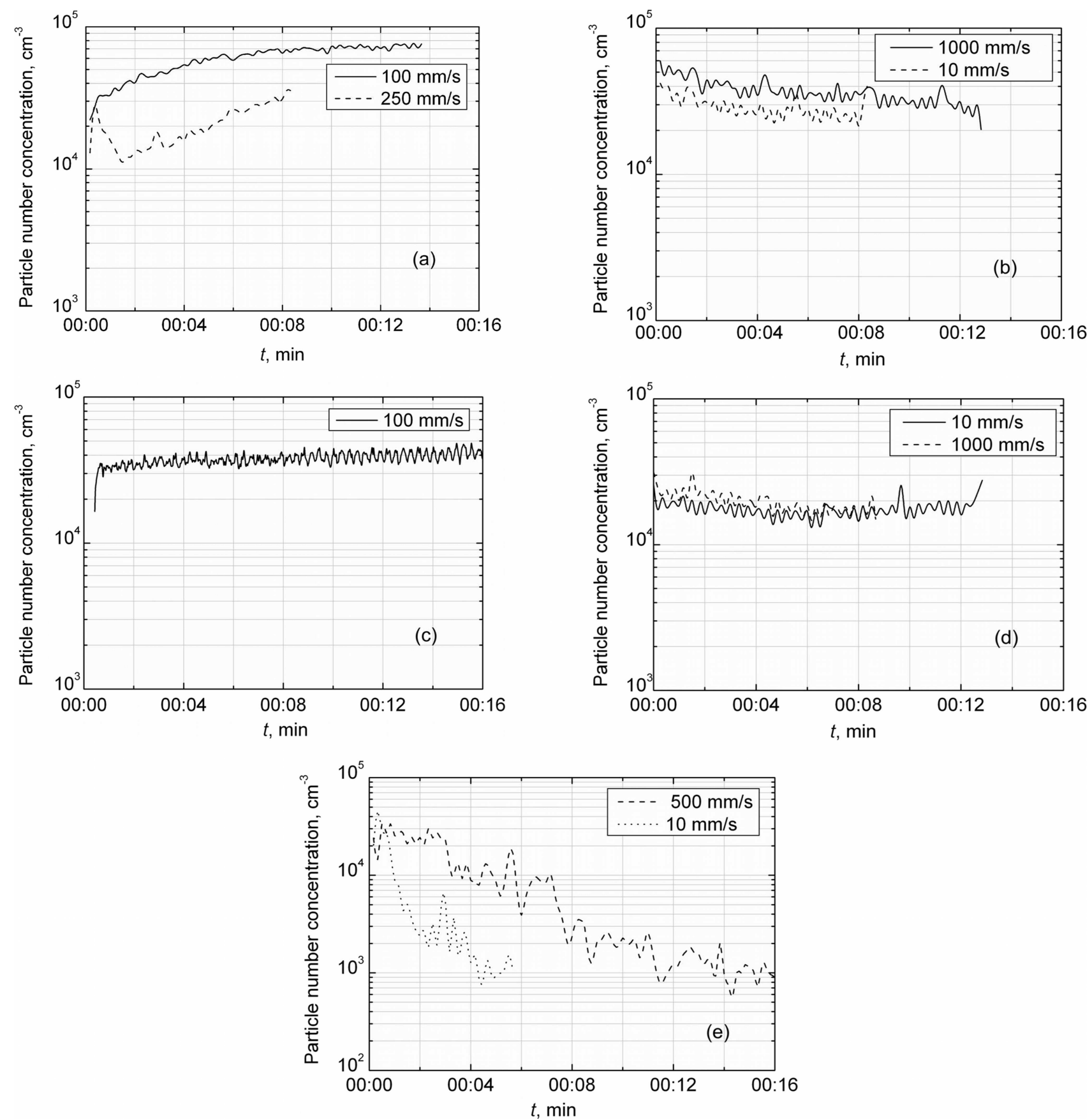

Fig. 4. Dynamics of generated particle number concentration during laser ablation of various metals in ambient air: (a) nickel by ns-laser at $0.4 \mathrm{~W}, 20 \mathrm{kHz}, 1.59 \mathrm{~J} / \mathrm{cm}^{2}$ and (b) by ps-laser at $0.49 \mathrm{~W}, 100 \mathrm{kHz}, 1.56 \mathrm{~J} / \mathrm{cm}^{2}$; (c) tungsten by ns-laser at $0.85 \mathrm{~W}, 22 \mathrm{kHz}, 3.07 \mathrm{~J} / \mathrm{cm}^{2}$ and (d) by ps-laser at $0.25 \mathrm{~W}, 100 \mathrm{kHz}, 1.80 \mathrm{~J} / \mathrm{cm}^{2}$; (e) aluminium by ns-laser at $0.6 \mathrm{~W}, 50 \mathrm{kHz}, 3.82 \mathrm{~J} / \mathrm{cm}^{2}$. 

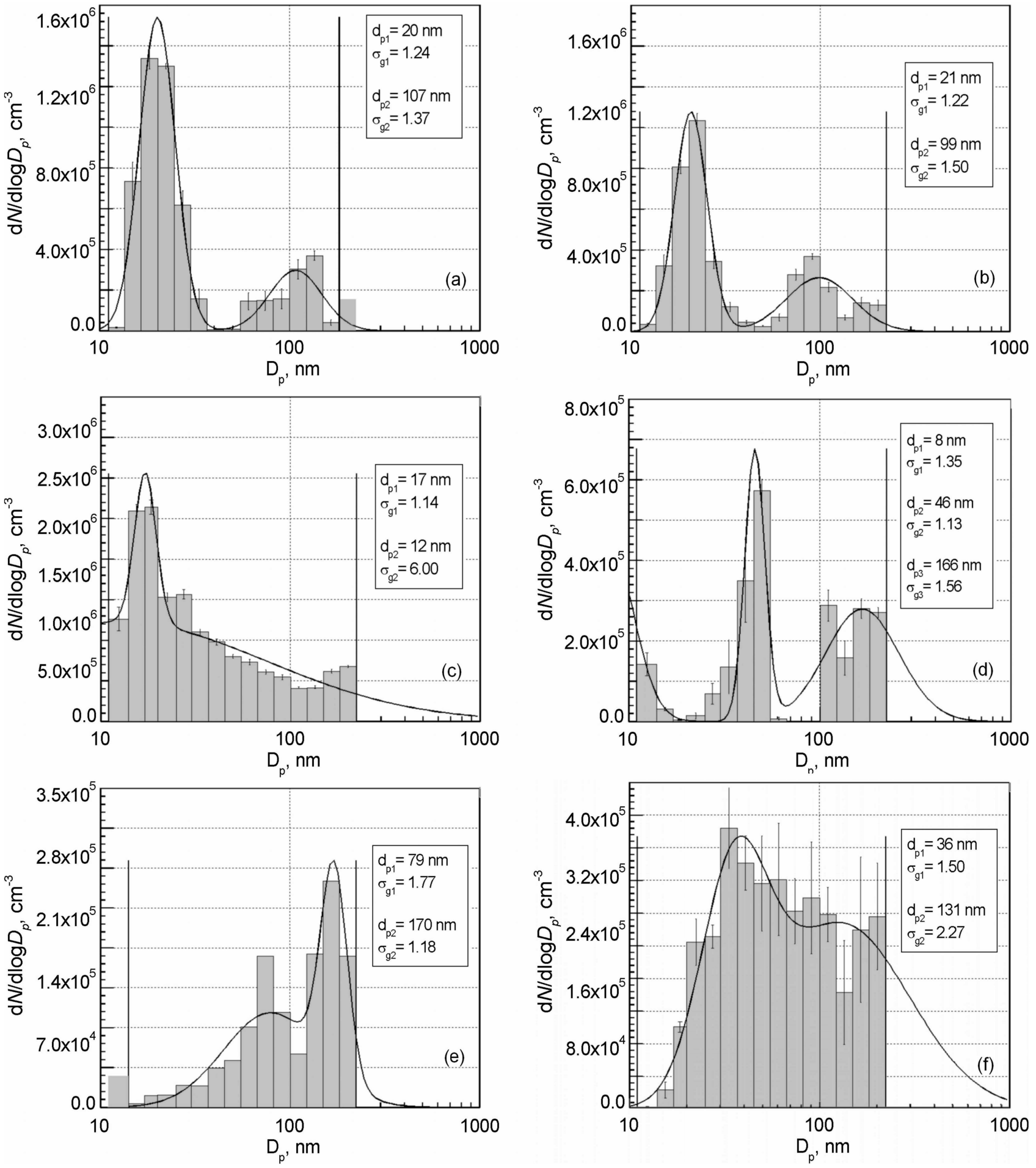

Fig. 5. Particle size $D_{\mathrm{p}}$ distribution for the ns-laser ablation of various metals in argon gas: (a) nickel at $2.7 \mathrm{~W}, 30 \mathrm{kHz}, 10 \mathrm{~mm} / \mathrm{s}, 7.16 \mathrm{~J} / \mathrm{cm}^{2}$; (b) aluminium at $1.36 \mathrm{~W}, 20 \mathrm{kHz}, 100 \mathrm{~mm} / \mathrm{s}, 5.41 \mathrm{~J} / \mathrm{cm}^{2}$; (c) stainless steel at $1.75 \mathrm{~W}, 5 \mathrm{kHz}, 10 \mathrm{~mm} / \mathrm{s}, 27.85 \mathrm{~J} / \mathrm{cm}^{2}$, and the ps-laser ablation in argon gas: (d) nickel at $1.5 \mathrm{~W}, 50 \mathrm{kHz}, 100 \mathrm{~mm} / \mathrm{s}, 9.55 \mathrm{~J} / \mathrm{cm}^{2}$; (e) aluminium at $0.6 \mathrm{~W}, 50 \mathrm{kHz}, 100 \mathrm{~mm} / \mathrm{s}, 3.82 \mathrm{~J} / \mathrm{cm}^{2}$; (f) tungsten at $1.2 \mathrm{~W}, 100 \mathrm{kHz}, 100 \mathrm{~mm} / \mathrm{s}, 3.82 \mathrm{~J} / \mathrm{cm}^{2}$. 
distribution depend on the experimental medium, target material properties, and laser process parameters. At first, the formation of nanoparticles and their size were affected by parameters of laser irradiation - the intensity, pulse length, and radiation wavelength. Our experimental data showed that the smallest $(\sim 8 \mathrm{~nm})$ particles of nucleation mode were formed by the picosecond laser ablation (Figs. 3 and 5). Larger (17-21 nm) particles of nucleation mode were generated during the nanosecond laser ablation.

Different physical mechanisms of the laser beam/ matter interaction for ns- and ps-lasers have an effect on the diameter of generated particles. The primary thermal nature of nanosecond laser ablation can lead to formation of a molten layer and ejection of melted particles at evaporation, in addition to particles formed from condensation [1]. The metal surface impacted by picosecond laser radiation can be attributed to electrons and mass emitted from the target surface, while particle generation after several $10 \mathrm{~ns}$ pulses proceeds due to emission of particles and droplets after a thermal boiling process. Vaporized material, in contact with metal, is ionized and over the target surface formation of plasma cloud from electrons, ions, and particles of metals starts [5, 11, 19, 21]. Our registered smallest nickel particles of nucleation mode $(\sim 8 \mathrm{~nm})$ by the ps-laser ablation can be produced during this process (Figs. 3 and 5).

Experimental results have shown that the generated particles (nickel, aluminium) during the ps-laser ablation are characterized by the maximum in the particle size range of 160-170 $\mathrm{nm}$, while during the ns-laser ablation particles of size range of $90-110 \mathrm{~nm}$ were produced (Table 1).

The effects of various laser process parameters on the nickel particle size and number concentration during the nanosecond laser ablation in argon gas at four different laser intensities were observed, and two almost identical narrow peaks of size distribution of particles for all energies were obtained (Fig. 6(a)). Two narrow peaks of nickel particles in the range of 14-18 nm and $100-150 \mathrm{~nm}$ at pulse energies from 90 to $207 \mu \mathrm{J}$ were observed. It should be noted that by changing the laser beam scanning speed $(10 \mathrm{~mm} / \mathrm{s}$ or $100 \mathrm{~mm} / \mathrm{s})$ the difference in the particle concentration and size distribution was very small.

The same results were observed in experiments with aluminium (Fig. 6(b)). Two narrow peaks of particles in the range of 20-24 nm and $80 \mathrm{~nm}$ at laser pulse energies from 47 to $89 \mu \mathrm{J}$ with stable particle number concentration by changing the laser beam scanning speed (100
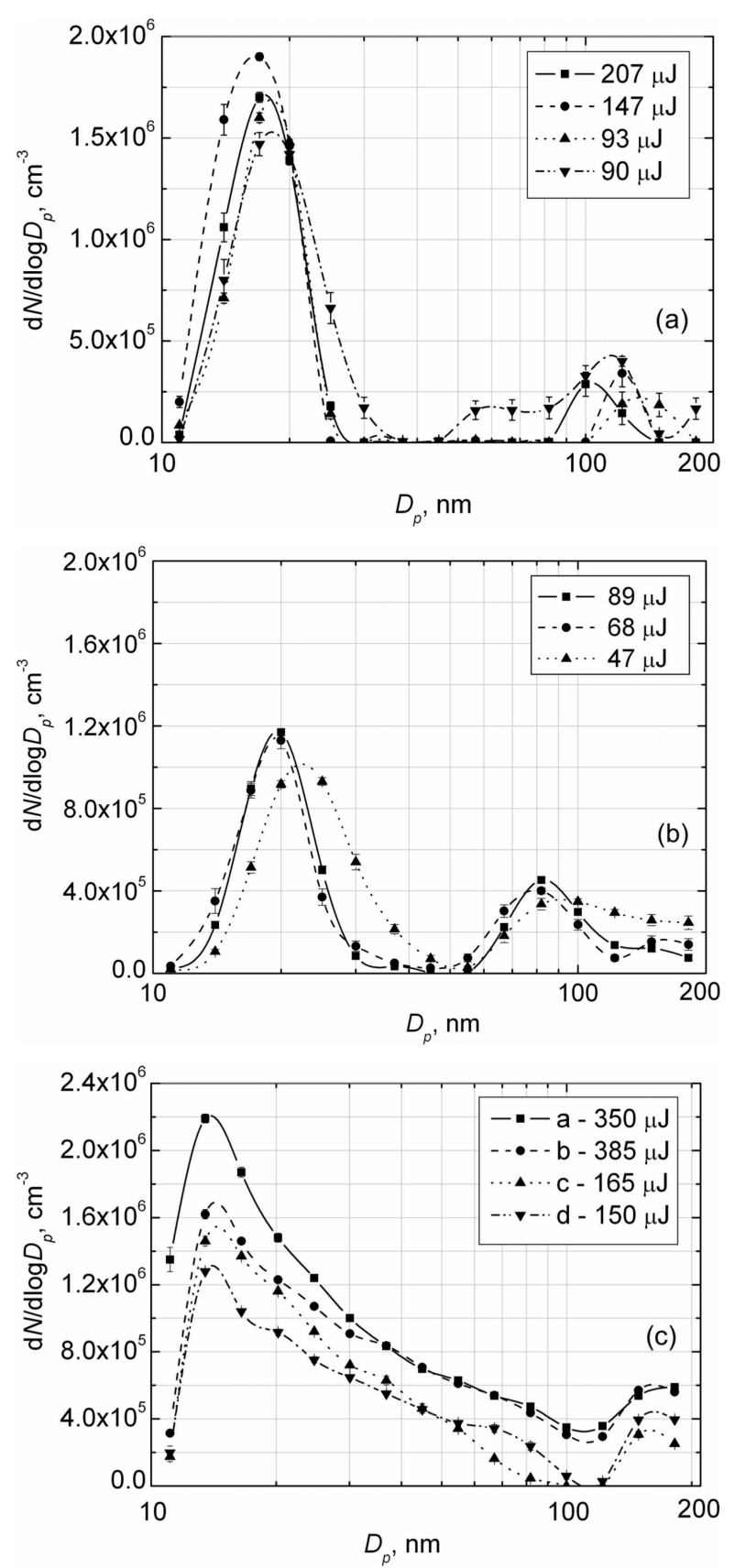

Fig. 6. Particle size $D_{\mathrm{p}}$ distribution for ns-laser ablation of metals in argon gas at different beam intensities: (a) nickel at $10-30 \mathrm{kHz}, 10$ $100 \mathrm{~mm} / \mathrm{s}\left(16.47,11.70,7.40\right.$, and $7.16 \mathrm{~J} / \mathrm{cm}^{2}$ respectively to the laser pulse energy), (b) aluminium at $10-20 \mathrm{kHz}, 100-500 \mathrm{~mm} / \mathrm{s}$ (7.08, 5.41, and $3.74 \mathrm{~J} / \mathrm{cm}^{2}$ respectively to the laser pulse energy), and (c) stainless steel at $1-20 \mathrm{kHz}, 10-100 \mathrm{~mm} / \mathrm{s}(27.85,30.64$,

13.13 , and $11.94 \mathrm{~J} / \mathrm{cm}^{2}$ respectively to the laser pulse energy).

or $1000 \mathrm{~mm} / \mathrm{s}$ ) were obtained. The production of the maximum number concentration of metal particles by laser ablation in argon was reached: for nickel at $93 \mu \mathrm{J}$, stainless steel at $350 \mu \mathrm{J}$, and aluminium at $89 \mu \mathrm{J}$.

As seen in Fig. 6(c), the largest effect on stainless steel particle generation at various $(150-385 \mu \mathrm{J}) \mathrm{ns}-$ 
laser pulse energies was observed at $350 \mu \mathrm{J}$ pulse energy and the beam scanning speed of $10 \mathrm{~mm} / \mathrm{s}$.

The variations of the nickel particle number concentration only of the smallest size particles (10-12 nm) during the ps-laser ablation in argon gas by changing the laser beam scanning speed (100 or $1000 \mathrm{~mm} / \mathrm{s})$ were observed. In case of stainless steel during the ns-laser ablation by changing the beam scanning speed from 10 to $100 \mathrm{~mm} / \mathrm{s}$, the particle number concentration varied about two times in the range of $14-18 \mathrm{~nm}$. The optimal regime for particle generation (nickel and stainless steel) was observed at the following laser parameters: the pulse frequency $10 \mathrm{kHz}$ and the beam scanning speed $100 \mathrm{~mm} / \mathrm{s}$.

As seen in Figs. 2, 3, and 5, the size distribution and number concentration of generated metal particles during laser ablation in ambient air differed from those in argon gas. First of all, we consider that formation of particle size and their number concentration was influenced by the complex of precursors (oxygen, water vapour, suspended matter $<5 \mathrm{~nm}$, etc.) present in ambient air, which was passing through the ablation chamber. Precursors themselves are actively forming various chemical compounds with generated metal particles $\left(\mathrm{NiO}, \mathrm{Al}_{2} \mathrm{O}_{3}, \mathrm{FeO}\right)$ during the ablation. Studies of particle formation by Gonzalez et al. [1] show that the particle size strongly depends on the precursor concentration (atoms and clusters), which will affect the size of the primary particles. The oxidation process of nickel particles during laser ablation in ambient air is shown in works of Liu et al. [5]. For example, in Fig. 2 it can be seen that the nickel particle size spectrum is wide and the generation of particles by the ns-laser in narrow ranges was not observed. The standard deviation of the generated particle number concentration at $61 \mathrm{~nm}$ was $\sigma_{g}=3.21$ and only a sharp peak of smallest nickel particles at $18 \mathrm{~nm}\left(\sigma_{g}=1.15\right)$ was observed.

Investigation of the nickel particle formation by the ns- and ps-laser ablation in ambient air showed that the influence of precursors on the particle size and concentration was different as well. The size distribution of the generated nickel particles showed that during the pslaser ablation in argon gas the smallest particles in the nucleation mode $\left(d_{\mathrm{p}}=8 \mathrm{~nm}\right)$ and coarser particles in Aitken $\left(d_{\mathrm{p}}=46 \mathrm{~nm}\right)$ and accumulation $\left(d_{\mathrm{p}}=166 \mathrm{~nm}\right)$ modes were produced (Fig. 5(d)). The standard deviations of the particle concentration for these sizes were $\sigma_{g}=1.35, \sigma_{g}=1.13$, and $\sigma_{g}=1.56$, respectively. In addition to the particle size in the range from $10 \mathrm{~nm}$ to $100 \mathrm{~nm}$ for nickel during ps-laser ablation in ambient air the influence of precursors was observed, except for particles less than $8 \mathrm{~nm}$ with $\sigma_{g}=1.37$ (Fig. 3(a)). Comparison of the aluminium particle size with the size of nickel and tungsten particles under the same ablation conditions (ambient air, ps-laser) showed a wide variety range of all particles (Fig. 3). Aluminium particles in a wide range with peaks at $20 \mathrm{~nm}$ (the standard deviation $\left.\sigma_{g}=1.31\right)$ and with a negligible peak at $43 \mathrm{~nm}$ $\left(\sigma_{g}=2.32\right)$ were formed (Fig. 3(b)). Based on aluminium properties, it is possible to explain that the ablated particles can be originated from $\mathrm{Al}_{2} \mathrm{O}_{3}$. A constant film of aluminium oxide is formed on the surface of this metal in contact with air [10].

Besides, the influence of precursors during the picosecond laser ablation in ambient air was observed in case of generated tungsten particles. As seen in Fig. 3(c), Aitken mode particles dominated $\left(d_{\mathrm{p}}=\right.$ $\left.31 \mathrm{~nm}, \sigma_{g}=2.46\right)$ in a wide size spectrum. The accumulation mode was clearly distinguished in the particle size distribution $\left(d_{\mathrm{p}}=186 \mathrm{~nm}, \sigma_{g}=1.13\right)$. In general, the particle generation of all investigated metals in ambient air was very small.

Experimental data of particle formation by the nsand ps-laser ablation in argon gas have shown that the particle size distribution and concentration depended on the processed metal characteristics, on the laser process parameters as well as on the thermodynamic conditions in the processed zone. For example, during the ns-laser ablation in argon gas smaller particles were produced $(17-21 \mathrm{~nm})$ than during the ps-laser ablation, except for nickel particles $\left(d_{\mathrm{p}}=8 \mathrm{~nm}, \sigma_{g}=1.35\right)$ (Table 1 , Fig. 5(a,d)).

Furthermore, the dependence of the nanoparticle size distribution on material properties of various metals during the ns- or ps-laser ablation was observed. The laser pulse energy influencing the size distribution of nanoparticles generated during laser ablation of various materials depends on their reflectivity [10]. The smallest particles are generated at higher pulse energies, but a size shift decreases for materials with lower reflectivity.

Our measurement data showed that during the nslaser ablation of stainless steel, nickel, and aluminium the shift to a smaller size range was observed at higher pulse energy in metals with lower reflectivity. We observed the smallest generated particles $\left(d_{\mathrm{p}}=17 \mathrm{~nm}\right)$ of stainless steel (34\% of reflectivity) at $350 \mu \mathrm{J}$ pulse energy as aluminium (reflectivity - 91\%) generated particles were of $21 \mathrm{~nm}$ magnitude at $89 \mu \mathrm{J}$ pulse energy (Fig. 6, Table 2).

The explanation for separate number concentrations of nanoparticles and their size spectrum of investigated metals is more complicated due to the different physical 
Table 2. Physical properties of investigated metals.

\begin{tabular}{lccccc}
\hline Metals & $\begin{array}{c}\text { Thermal } \\
\text { conductivity } \\
K, \mathrm{~W} /(\mathrm{cm} \mathrm{K})\end{array}$ & $\begin{array}{c}\text { Density } \rho, \\
\mathrm{g} / \mathrm{cm}^{3}\end{array}$ & $\begin{array}{c}\text { Melting point } \\
T_{\mathrm{M}}, \mathrm{K}\end{array}$ & $\begin{array}{c}\text { Boiling point } \\
T_{\mathrm{B}}, \mathrm{K}\end{array}$ & $\begin{array}{c}\text { Reflectivity } \\
\text { coefficient } R\end{array}$ \\
\hline Aluminium (Al) & 2.37 & 2.7 & 933 & 2467 & 0.91 \\
Tungsten (W) & 1.74 & 19.3 & $3673-3683$ & 5930 & 0.49 \\
Stainless steel (302) & 0.16 & $7.8-8$ & $1644-1672$ & 3000 & 0.34 \\
Nickel (Ni) & 0.91 & 8.9 & 1726 & 3005 & 0.70 \\
\hline
\end{tabular}

properties of each material. As can be seen in Fig. 5, a major variety of discrepancy of modes of produced particles among metals is observed during the picosecond laser ablation. Our results for tungsten are in agreement with [22] where an increase in the formation of larger particles of elements with a high melting point was determined. As seen in Table 2, the melting point of tungsten is highest among investigated metals, and a wide size spectrum of generated tungsten particles with a shift to the coarse particle size compared to other metals was observed (Fig. 5).

According to the investigations by Gonzalez et al. [1], Brikas [10], and Hola et al. [22], the influence of material properties on the size and concentration of particles generated by the nanosecond laser ablation is important. The higher number concentration of stainless steel and nickel particles produced by the ns-laser (Table 1) could be related to the lowest thermal conductivity of these metals compared with other investigated metals (Table 2). Generally, the generation of stainless steel, nickel, and aluminium particles by the ns-laser ablation in argon gas was the most intensive.

\section{Conclusion}

The peculiarities of nanoparticle formation during the ns- and ps-lasers ablation of nickel, aluminium, stainless steel, and tungsten in ambient air and argon gas were investigated experimentally.

It was found that the size distribution and number concentration of generated metal particles during the laser ablation in ambient air differed from those in argon gas medium. The number concentrations of generated nanoparticles during the laser ablation in argon gas, compared to the produced nanoparticle concentrations in ambient air, were up to 100 times higher and characterized by separate stable size peaks (nucleation, Aitken, and accumulation modes) of nanoparticles, while a wide size spectrum (from 8 to $200 \mathrm{~nm}$ ) of generated nanoparticles without clear separation of the size modes in ambient air was observed. The natural precursors in ambient air can have an effect on the size spectrum of particles composed of various chemical compounds with target material during ablation process.

Primary particles of $8 \mathrm{~nm}$ size during the ps-laser ablation and of 17-21 nm size in nucleation mode by the ns-laser ablation were produced. It was evidently caused by different physical processes in the laser beam/material interaction zone.

The influence of laser process parameters on the number concentration and a shift in dynamics of size distribution of nanoparticles generated during the nsand ps-laser ablation in argon gas were observed. The maximum number concentration of generated metal particles by laser ablation in argon was reached: for nickel at $93 \mu \mathrm{J}$, stainless steel at $350 \mu \mathrm{J}$, and aluminium at $89 \mu \mathrm{J}$. Moreover, the dependence of the investigated metal properties (reflectivity, melting point, and thermal conductivity) on the size distribution and number concentration of generated nanoparticles was determined.

The study showed that according to particular laser process parameters during the nanosecond and picosecond laser ablation in argon gas the generation of stable separate modes of nickel and aluminium particle size distribution can be controlled.

Further investigations will focus on the development of technology of generation of monodisperse metal nanoparticles (the standard deviation $\sigma_{g}=1.1$ ) based on primary and secondary particle formation physical processes.

\section{References}

[1] J.J. Gonzalez, C. Liu, S.-B. Wen, X. Mao, and R.E. Russo, Metal particles produced by laser ablation for ICP-MS measurements, Talanta 73(3), 567576 (2007).

[2] S.-B. Wen, X. Mao, R. Greif, and R.E. Russo, Experimental and theoretical studies of particle generation after laser ablation of copper with a background gas at atmospheric pressure, J. Appl. Phys. 101, 123105 (2007).

[3] S. Barcikowski, A. Hahn, A.V. Kabashin, B.N. Chichkov, Properties of nanoparticles gen- 
erated during femtosecond laser machining in air and water, Appl. Phys. A 87, 47-55 (2007).

[4] D. Breitling, A. Ruf, and F. Dausinger, Fundamental aspects in machining of metals with short and ultrashort laser pulses, Proc. SPIE 5339, 49 (2004).

[5] B. Liu, Z. Hu, Y. Che, Y. Chen, and X. Pan, Nanoparticle generation in ultrafast pulsed laser ablation of nickel, Appl. Phys. Lett. 90, 044103 (2007).

[6] M.-H. Tsai, S.-Y. Chen, and P. Shen, Laser ablation condensation of $\mathrm{TiO}_{2}$ particles: Effects of laser energy, oxygen flow rate and phase transformation, J. Aerosol Sci. 36, 13-25 (2005).

[7] D.-W. Lee and M.-D. Cheng, Particle generation by laser ablation during surface decontamination, J. Aerosol Sci. 35, 1527-1540 (2004).

[8] S. Barcikowski, A. Hahn, A.V. Kabashin, and B.N. Chichkov, Nanoparticles as potential risk during femtosecond laser ablation, J. Laser Appl. 19(2), 65-73 (2007)

[9] N. Morris, The fine art of micromachining, ElectroOptics.com (2006), http://electrooptics.com/features/ aprmay06/aprmay06micromachines.html .

[10] M. Brikas, Micromachining of silicon and metals with high repetition rate picosecond laser, $\mathrm{PhD}$ thesis, Vilnius University and Institute of Physics, Center for Physical Sciences and Technology, Vilnius (2011) [in Lithuanian].

[11] T.V. Kononenko, V.I. Konov, S.V. Garnov, R. Danielius, A. Piskarskas, G. Tamoshauskas, and F. Dausinger, Comparative state of the ablation of materials by femto second and pico- or nanosecond laser pulses, Quantum Electron. 29(8), 724-728 (1999).

[12] N.B. Dahotre and S.P. Harimkar, in: Laser Fabrication and Machining of Materials (Springer Science, 2008) pp. 34-65.
[13] B.N. Chichkov, C. Momma, S. Nolte, F. von Alvensleben, and A. Tünnermann, Femtosecond, picosecond and nanosecond laser ablation of solids, Appl. Phys. A 63(2), 109-115 (1996).

[14] K. Plauškaitè, V. Ulevicius, N. Špirkauskaitė, S. Byčenkienè, T. Zieliński, T. Petelski, and A. Ponczkowska, Observations of new particle formation events in the south-eastern Baltic Sea, Oceanologia 52(1), 53-75 (2010).

[15] G. Mordas, M. Kulmala, T. Petäjä, P.P. Aalto, V. Matulevičius, V. Grigoraitis, V. Ulevičius, V. Grauslys, A. Ukkonen, and K. Hämeri, Design and performance characteristics of a condensation particle counter UF02proto, Boreal Env. Res. 10, 543-552 (2005).

[16] W. Haaf and R. Jaenicke, Results of improved size distribution measurements in the Aitken range of atmospheric aerosols, J. Aerosol Sci. 11(3), 321-330 (1980).

[17] www.distfit.com/Front/DistFit/DistFit_Brochure.pdf .

[18] E.G. Gamaly, N.R. Madsen, M. Duering, A.V. Rode, V.Z. Kolev, and B. Luther-Davies, Ablation of metals with picosecond laser pulses: Evidence of long-lived nonequilibrium conditions at the surface, Phys. Rev. B 71, 174405 (2005).

[19] J. Konig, S. Nolte, and A. Tünnermann, Plasma evolution during metal ablation with ultrashot laser pulses, Opt. Express 13(26), 10597 (2005).

[20] A. Hahn, S. Barcikowski, and B.N. Chichkov, Influences on nanoparticle production during pulsed laser ablation, j. laser micro/nanoeng. 3(2), 73-77 (2008).

[21] M.S. Tillack, D.W. Blair, and S.S. Harilal, The effect of ionization on cluster formation in laser ablation plumes, Nanotechnol. 15, 390-403 (2004).

[22] M. Holá, V. Konečná, P. Mikuška, J. Kaiser, and V. Kanický, Influence of physical properties and chemical composition of sample on formation of aerosol particles generated by nanosecond laser ablation at 213 nm, Spectrochim. Acta Part B 65(1), 51-60 (2010). 


\title{
METALŲ NANODALELIŲ GENERAVIMAS LAZERINE ABLIACIJA
}

\author{
V. Dudoitis, V. Ulevičius, G. Račiukaitis, N. Špirkauskaite, K. Plauškaitė
}

Valstybinis moksliniu tyrimu institutas Fiziniu ir technologijos mokslu centras, Vilnius, Lietuva

\section{Santrauka}

Lazerinè abliacija, kaip efektyvus ir spartus įvairių medžiagų smulkių struktūrų formavimo būdas, pastaruoju metu vis sẻkmingiau i̊sitvirtina nanodarinių gamyboje. Metalai yra vieni iš tinkamiausių medžiagų mikrosistemoms gaminti. Norint formuoti tikslias mikrosistemas turi būti atliekami generuojamų nanodalelių dydžiu spektro bei koncentracijos eksperimentiniai tyrimai. Darbe nagrinèti nikelio, aliuminio, nerūdijančio plieno ir volframo nanodaleliu generavimo procesai, taikant nanosekundinès ir pikosekundinès trukmės impulsų lazerius. Nustatyta, kad generuojamų visų tirtų metalų nanodalelių dydžių spektras ir skaitinė koncentracija, vykstant lazerinei abliacijai oro ar argono dujų aplinkoje, ženkliai skiriasi. Vykstant lazerinei abliacijai ore generuojamos nanodalelių (1-12) $\cdot 10^{4} \mathrm{~cm}^{-3}$ koncentracijos bei 8-200 nm dydžiu platus spektras su nukleacinès ir akumuliacinès modų nedidelèmis smailėmis. Manome, kad atskirų dydžių generuojamų nanodalelių spektrui įta- kos turèjo oro sudèties komponentès, kurios abliacijos proceso metu dalyvavo cheminių junginiu susidaryme (pvz., $\mathrm{FeO}, \mathrm{NiO}, \mathrm{Al}_{2} \mathrm{O}_{3}$ ). Lazerinès abliacijos ore atveju argono duju aplinkoje generuojamos metalų nanodaleliu $(0,1-1,9) \cdot 10^{6} \mathrm{~cm}^{-3}$ koncentracijos su gerai besiformuojančiu nukleacinès, Aitkeno ir akumuliacinès modụ spektru. Stebèta lazerinès abliacijos parametrų ir metalų savybiu ¡taka generuojamų nanodalelių skaitinei koncentracijai bei daleliu dydžiu pasiskirstymo spektre poslinkiui. Mažiausios nanodalelès ( $\sim 8 \mathrm{~nm})$ generuotos abliuojant nikeli pikosekundinès trukmès impulso lazeriu argono dujų aplinkoje. Manome, kad registruotos pirminés nikelio dalelès galèjo būti generuojamos susidarius plazmai lazerinès spinduliuotès ir metalo sąveikos zonoje. Nerūdijančio plieno, nikelio ir aliuminio nanodaleliu (10-200 nm) generavimo procesas intensyviausiai vyko abliuojant metalus nanosekundinès trukmès impulso lazeriu argono dujose. 